\title{
CONTROL OUTPUT OF GENERATOR TRANSLATION AND ROTATION USING BUCK- BOOST CONVERTER FOR SEA WAVE POWER PLANT
}

\author{
Anizar Indriani \\ Department of Electrical Engineering, University of Bengkulu, \\ Bengkulu, Indonesia \\ Ija Darmana \\ Department of Electrical Engineering, University of Bung Hatta, \\ Padang, Indonesia \\ Hernadewita \\ Department of Industrial Engineering, University of Mercubuana, \\ Jakarta, Indonesia \\ Ari Setyawan \\ Department of Electrical Engineering, University of Bengkulu, \\ Bengkulu, Indonesia

\section{Hendra} \\ Department of Mechanical Engineering, University of Sultan Ageng Tirtayasa, \\ Banten, Indonesia
}

\begin{abstract}
Generators are the main components of the power generation system. The generators function to convert mechanical energy into electrical energy by using rotation and translation motion mechanisms. Generator with rotation motion mechanism can be seen on the turbine. While the translation motion generator can be seen in the Pelamis, pneumatic, and other systems. Rotation and translation motion generators consist of rotor components, stators, rotor/stator mounts and more. Performance generator depends on generator drive system, magnet material, magnetic distance, number of coil, dimensional coil and others. In this paper focus on the translation and rotation motion generator mechanism with the drive source in the form of horizontal thrust power (substitute the motion down and up the sea waves). Where the generator output has an unstable voltage so that it cannot be used to charge the battery. To overcome this problem Buck-Boost Converter are used to control output of generator stable. In this research experimental method is applied
\end{abstract}


using a horizontal directional generator mounting structure. Horizontal thrust force is used as the source of the translation of the translation motion generator. The number pole is 4 and 1260 coil winding for translation motion generator. Rotation motion generator using permanent magnet generator with 170 coil winding. The results showed that before using Buck-Boost Converter the output voltage of the translation and rotation motion generators is fluctuated between 18.1-40.14 Volts. After using Buck-Boost Converter, the voltage output of generator become stable at 23.93-24.11 Volts and it can be used to charge the battery.

Keywords: Translation motion generator; rotation motion generator; Buck-Boost Converter; battery; magnet neodymium.

Cite this Article: Anizar Indriani, Ija Darmana, Hernadewita, Ari Setyawan, Hendra, Control Output of Generator Translation and Rotation using Buck-Boost Converter for Sea Wave Power Plant. International Journal of Mechanical Engineering and Technology. 11(5), 2020, pp. 61-74.

https://iaeme.com/Home/issue/IJMET?Volume $=11 \&$ Issue $=5$

\section{INTRODUCTION}

The generator is a machine component to produce electricity by converting mechanical energy into electrical energy. The main component of generator consists a rotor and stator. Working principle of generator is rotor and stator on the generator driven by motion mechanism as rotation and translation. The mechanism motion of generator is obtained by natural resources such as water, wind, fossil, geothermal, ocean wave and etc. Rotation motion generator can be works by using turbine to rotate the generator. Rotation motion generators have been found in hydro power, wind, fossil and geothermal power plants. The translation motion generators can be seen in ocean wave power plants [1-3]. Translation motion generator utilize pneumatic or kinematic mechanisms to drive piston up and down motion following sea wave length and it found at pneumatic mechanism [1-3], Pelamis mechanism, oscillating water column and etc. [4-9].

The mechanism of translation and rotation motion generators have advantages and disadvantages such as simple of process, easily to use and maintenance, requiring a lot of components for generator rotation, and the voltage is unstable in the translation motion generator due to up and down motions waves that are not constant. Performance of the generator depend on the distance gape of magnet and number of pole (winding coils), material of magnet, dimension of magnet and winding coil, motion of generator and soon.

Effect of unstable voltage made output of generator cannot be used for charged of battery. To solve this problem, Buck-Boost Converter are used for control the output of generator is stable. Therefore in this paper Buck-Boost Converter are consider for control output of the generator become stable. In previous study this generator are used ocean wave resources (sea wave length) for drive of generators. In this research manual resources are used to drive motion of generator up and down following the ocean wave motion during. Translation motion generators produce $\mathrm{AC}$ voltage and rotation motion generators produce $\mathrm{DC}$ voltage. This research focus on the performance of translation and rotation motion generators using Buck-Boost Converter to get the output of generator is stable (AC and DC voltages) and also to synchronize the output voltage of this generator. The Buck-Boost Converter aims to align the voltage and frequency of the translation generator output and rotation in parallel so that the same voltage is obtained. 


\section{METHODS AND MATERIALS}

\subsection{Generators}

Generator is a machine component to convert mechanical energy into electrical energy. Mechanical energy by combination of potential and kinetic energys. Potential energy generated by some resources such as water, air, steam, wind, ocean waves and others that will be drive the components in a rotating generator and changing into electrical energy through the stator coil and rotor magnet. Electrical energy produced by generators can be alternating current (AC) or direct current (DC).

\subsection{Translation and Rotation Motion Generator}

The working principle of translation motion generator is piston up and down motion in the generator depend on the direction of sea wave motion. The frequency of the generator can be calculated by equation 1 .

$\mathrm{f}=\frac{\mathrm{N}_{\mathrm{r}} \times \mathrm{p}}{120}$

Where:

$\mathrm{f} \quad=$ frequency $(\mathrm{Hz})$

$\mathrm{N}_{\mathrm{r}}=$ Rotor velocity (rpm)

$\mathrm{p}=$ Number poles

\subsection{Component Translation and Rotation Motion Generators}

The translation and rotation motion generators have two prime of component is stator and rotor as shown in Figure 1. The construction of the translation and rotation motion generators design consists of the generator housing, the generator housing holder frame, neodymium magnet, piston, holder magnet, coil windings, permanent magnet generator and others. Design of translation and rotation motion generators using Buck- Boost Converter can be seen in Figure 2.

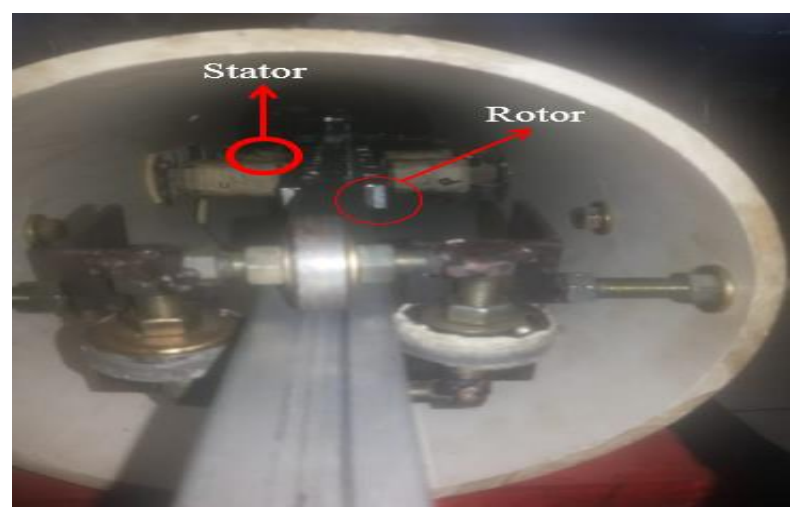

Figure 1 Construction of Generator Translation 


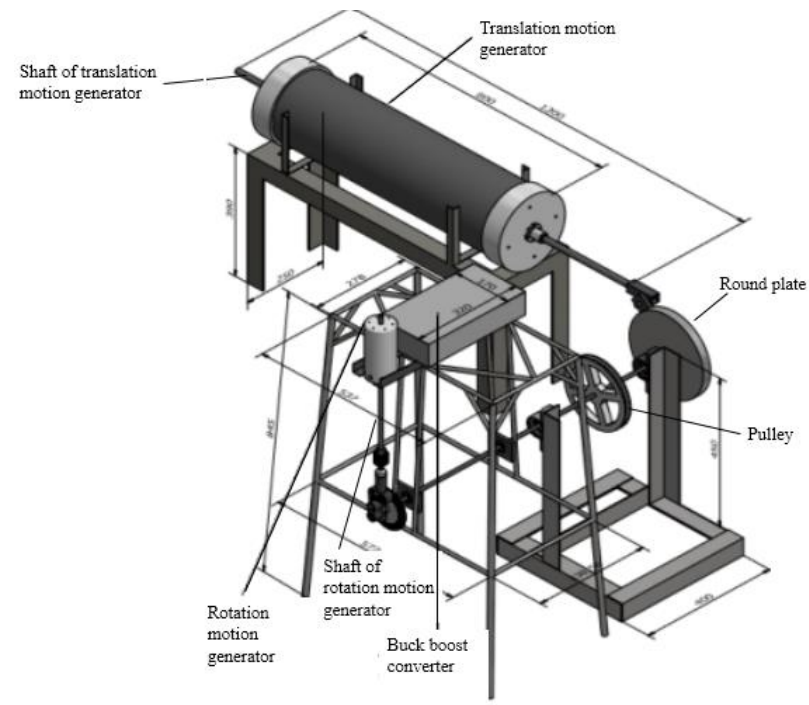

Figure 2 Design of translation motion and rotation generators using Buck-Boost Converter

\subsection{Calculation of Power Generator}

Electric power of generator can be calculated by Eq. 2 [10].

$\mathrm{P}=V \times I$

Where:

$\mathrm{P}=$ Power (Watt)

$\mathrm{V}=$ Voltage $($ Volt $)$

$\mathrm{I}=$ Current (Ampere)

\subsection{Buck-Boost Converter}

Buck-Boost Converter is used for stable output of generator by control of raising or lowering the voltage. The Buck-Boost Converter circuit can be seen in Figure 3. Parameters in the Buck-Boost Converter are duty cycle (D), inductor, resistor, capacitor and others as shown in Fig. 3. The duty cycle of Buck-Boost Converter can be calculated by using equation 3-4 [11, 12]. Figure 4 show that mechanism of Buck-Boost Converter which output of translation and rotation motion generator are detect by sensor of voltage and current. Then microcontroller will be controlled the output of generator to DC- DC and also the voltage then continue to charge of battery.

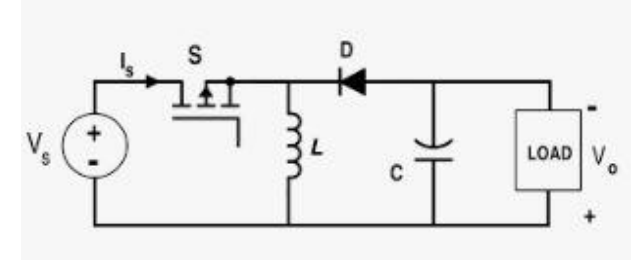

Figure 3 Schematic of Buck-Boost Converter

$\frac{\mathrm{V}_{\mathrm{o}}}{\mathrm{V}_{\text {in }}}=\frac{\mathrm{D}}{1-\mathrm{D}}$

$\mathrm{D}=\frac{\mathrm{t}_{\text {on }}}{\mathrm{t}_{\text {on }}+\mathrm{t}_{\text {off }}}=\frac{\mathrm{t}_{\text {on }}}{\mathrm{T}}$

Where: 


$$
\begin{array}{ll}
\mathrm{V}_{\mathrm{o}} & =\text { Voltage out of converter (Volt) } \\
\mathrm{V}_{\text {in }} & =\text { Voltage in of converter (Volt) } \\
\mathrm{D} & =\text { Duty Cycle } \\
\mathrm{t}_{\mathrm{on}} & =\text { Time switch for close (s) } \\
\mathrm{t}_{\mathrm{off}} & =\text { Time switch for open (s) } \\
\mathrm{T} & =\text { Cycle period of Buck-Boost Converter (s). }
\end{array}
$$

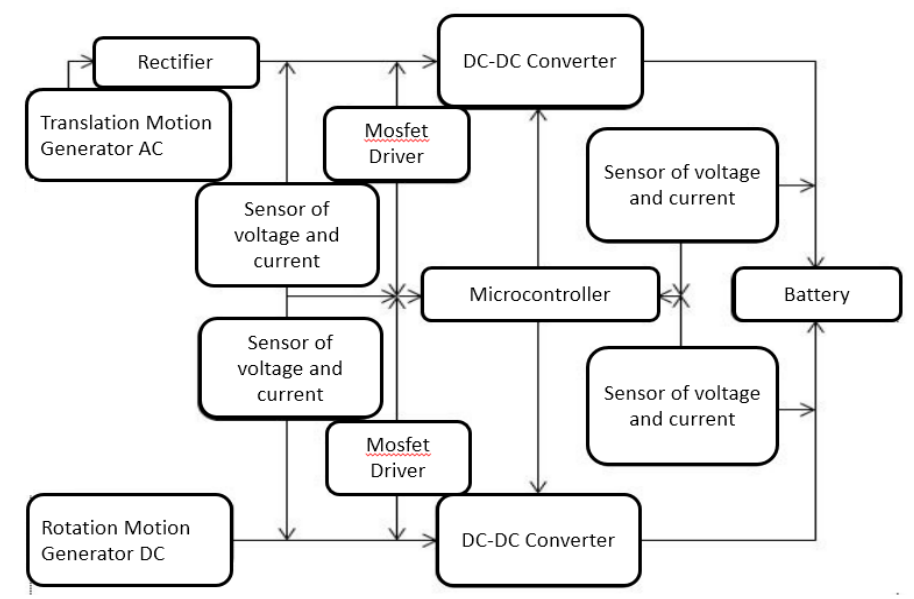

Figure 4 Diagram of Buck-Boost Converter

\subsection{Design of Translation and Rotation Motion Generator}

The design of translation and rotation motion generators using Buck-Boost Converter can be seen in Figure 2. The generator have several components such as translation motion generator, rotation motion generator, pulley, Buck-Boost Converter, frame of generator, gear, connecting shaft and others. Translation motion generators consist of a generator housing, a magnetic holder shaft, neodymium magnet, coil winding, coil winding holder, bearings and other components. The design of translation motion generator include 4 rectangular neodymium magnets mounted on the two sides of the generator housing, 4x1260 coil windings with a diameter of $0.7 \mathrm{~mm}$, diameter of the generator housing $203.2 \mathrm{~mm}$ and size of magnetic holder shaft $1500 \mathrm{~mm}$ x $40 \mathrm{~mm}$. Rotation motion generator components consist of permanent magnet generators with a coil diameter of $0.4 \mathrm{~mm}$ and 175 coil winding.

Design of diagram Buck-Boost Converter for translation and rotation motions generator can be seen at Fig. 4 .

\subsection{Selection of Buck-Boost Converter Component}

Selection of Buck-Boost Converter depend on the duty cycle, inductor, capacitor, diode, Mosfet power and etc. The value of Buck-Boost Converter in this research is 0.67 duty cycle, $16 \Omega$ for resistor, impedance $220 \mu \mathrm{H}$, inductor $4.5 \mathrm{~A}$, and capacitor $1024 \mu \mathrm{F}$. Mosfet power is used type N MOSFET IRFZ44N with value of voltage 55V and 49A.

\subsection{The Schema of Power Output of Generator Translation and Rotation Motion Using Buck-Boost Converter}

The schematic of the power output for translation and rotation motion generators using BuckBoost Converter testing can be seen in Figure 5. In this research focus to obtained the control of performance of translation and rotation motion generators using Buck-Boost Converter in raising or lowering the voltage. Testing of translation and rotation motion generators is carried out with a load and without load. 


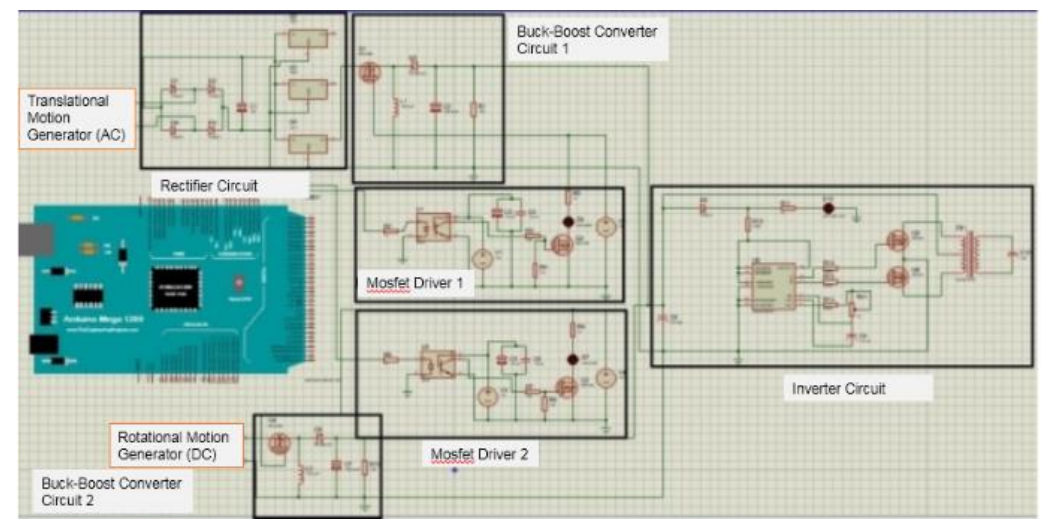

Figure 5 Schema testing of the power output for translation and rotation motion generators using Buck

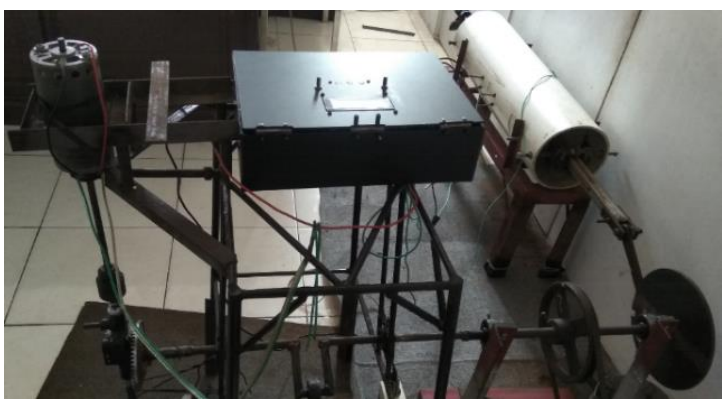

Figure 6 Translation and rotation motion generators using Buck-Boost Converter

\subsection{Testing Method of Performance of Translation and Rotation Motion of Generators}

Experimental method are used in the translation and rotation motion generator testing. Design of translation and rotation motion generator using Buck-Boost Converter can be seen in Fig. 1 and 6. In Figure 6 the design of translation and rotation motion generator consists of a translation motion generator, rotation motion generator, and frame holder of generator, shaft connecting the generator translation and rotation motion, stator and rotor. The output of translation and rotation motion generator is AC and DC. To control and synchronize the output of a translation and rotation motion generator, a bucks-Boost converter is used. Manual process are used to conduct the experimental process by push and pull of piston as shaft in the translation motion generator. Step testing of performance of generator is testing of performance component of Buck-Boost Converter, translation and rotation motion generators testing, translation and rotation motion generators without load and with load testing. The generators consist on the 2 pole in two side of tube generator for translation motion generator and number of winding coil $2 \times 1260$. The value of rotation to move the translation motion generator $100 \mathrm{rpm}$ to $200 \mathrm{rpm}$. Rotation motion generator using permanent magnet motor and varying of rotation similar with the translation motion generator (100 rpm to $200 \mathrm{rpm}$ ).

\section{RESULTS AND DISCUSSION}

\subsection{Result of Buck-Boost Converter Testing}

The performance of the Buck-Boost Converter in raising or lowering the voltage testing is done as shown in Table 1. Table 1 shows that the output voltage of the Buck-Boost Converter has the same value as the input value $(12 \mathrm{~V})$ if the value of duty cycle is equal to $50 \%$. The output voltage of the Buck-Boost Converter depend on the potentiometer value. With the 
increase of the potentiometer value, the output of voltage becomes increases and the value of duty cycle also increases. If the duty cycle is below $50 \%$, the output voltage becomes low (5 $\mathrm{V})$ and otherwise if it passes through the value of $50 \%$ the output voltage value increases $(23.34 \mathrm{~V})$. After testing performance of component Buck-Boost Converter is done, then the Buck-Boost Converter is used in to the translation and rotation generators to synchronize and control of stable the output voltage of generators.

Table 1 Results of Buck-Boost Converter Testing

\begin{tabular}{ccccccc}
\hline No. & $\begin{array}{c}\text { Vin } \\
(\mathbf{V})\end{array}$ & $\begin{array}{c}\text { Value of } \\
\text { potentiometer } \\
(\mathbf{K} \boldsymbol{\Omega})\end{array}$ & $\begin{array}{c}\text { Value of } \\
\text { Vout }(\mathbf{V})\end{array}$ & $\begin{array}{c}\text { Value of } \\
\text { Duty } \\
\text { Cycle } \\
(\boldsymbol{\%})\end{array}$ & $\begin{array}{c}\text { Calculation of } \\
\text { Duty Cycle } \\
(\boldsymbol{\%})\end{array}$ & $\begin{array}{c}\text { Error Duty } \\
\text { Cycle (\%) }\end{array}$ \\
\hline 1. & 12 & 0,861 & 5,06 & 33 & 29,6 & 3,4 \\
2. & 12 & 2,440 & 12,21 & 50 & 50,4 & 0,4 \\
3. & 12 & 4,99 & 23,34 & 67 & 66 & 1 \\
\hline
\end{tabular}

\subsection{Result of Translation Motion Generator Testing}

Translation motion generators testing carried out with a load and without load. Table 2 show that the testing of translation motion of generator using $2 \times 2160$ winding coil without load.

\subsection{Result of Translation Motion Generator Testing Without Load Using $2 \times 1260$ Winding Coil}

Translation motion generator testing without load using the number of winding coil $2 \times 1260$ by varying the rotation speed (100 rpm to $200 \mathrm{rpm})$. As shown in Table 2, the output of translation motion generator without load is unstable with the increasing of output voltage of generator from 23,67 V until 40,14 Volt during increasing of rotation speed of generator from $100 \mathrm{rpm}$ to $200 \mathrm{rpm}$. This result show that the output of generator cannot use for charger of battery. To control the output of generator to stable by using Buck-Boost Converter then we get the value of output generator become constant at 24,09 V to 24,13 Volt. Therefore by using Buck-Boost Converter, the output generator can be used for charge of battery because the output is stable at 24 Volt.

The shape of signal of the translation motion generator output voltage before using the Buck-Boost Converter as shown in Figure 7 a. The shape of signal of the output voltage of the generator is fluctuates and less stable (see Fig.7 a). After used a Buck-Boost Converter the output of generator is produces a stable and flat signal of generator output voltage as shown in Figure $7 \mathrm{~b}$.

Table 2 Two-Sided Of Translation Motion Generator Testing (2x1260 Winding Coil) Without Load

\begin{tabular}{lccccc}
\hline $\begin{array}{c}\text { Winding } \\
\text { coil (N) }\end{array}$ & $\begin{array}{c}\text { Rotation } \\
\text { (RPM) }\end{array}$ & \multicolumn{2}{c}{$\begin{array}{c}\text { Before using } \\
\text { Buck-Boost } \\
\text { Converter }\end{array}$} & \multicolumn{2}{c}{$\begin{array}{c}\text { After using Buck- } \\
\text { Boost Converter }\end{array}$} \\
\cline { 2 - 6 } & & $\begin{array}{c}\text { Voltage } \\
(\mathbf{V})\end{array}$ & $\begin{array}{c}\text { Isc } \\
(\mathbf{m A})\end{array}$ & $\begin{array}{c}\text { Voltage } \\
(\mathbf{V})\end{array}$ & $\begin{array}{c}\text { Isc } \\
(\mathbf{m A})\end{array}$ \\
\hline & 100 & 23,67 & 1,73 & 24,11 & 3,09 \\
& 120 & 27,99 & 1,73 & 24,13 & 3,08 \\
$2 \times 1260$ & 140 & 30,36 & 1,73 & 24,11 & 3,08 \\
& 150 & 31,9 & 2,11 & 24,10 & 3,09 \\
& 170 & 36,99 & 2,11 & 24,09 & 3,08 \\
& 190 & 39,81 & 2,81 & 24,10 & 3,09 \\
& 200 & 40,14 & 2,86 & 24,12 & 3,09 \\
\hline
\end{tabular}




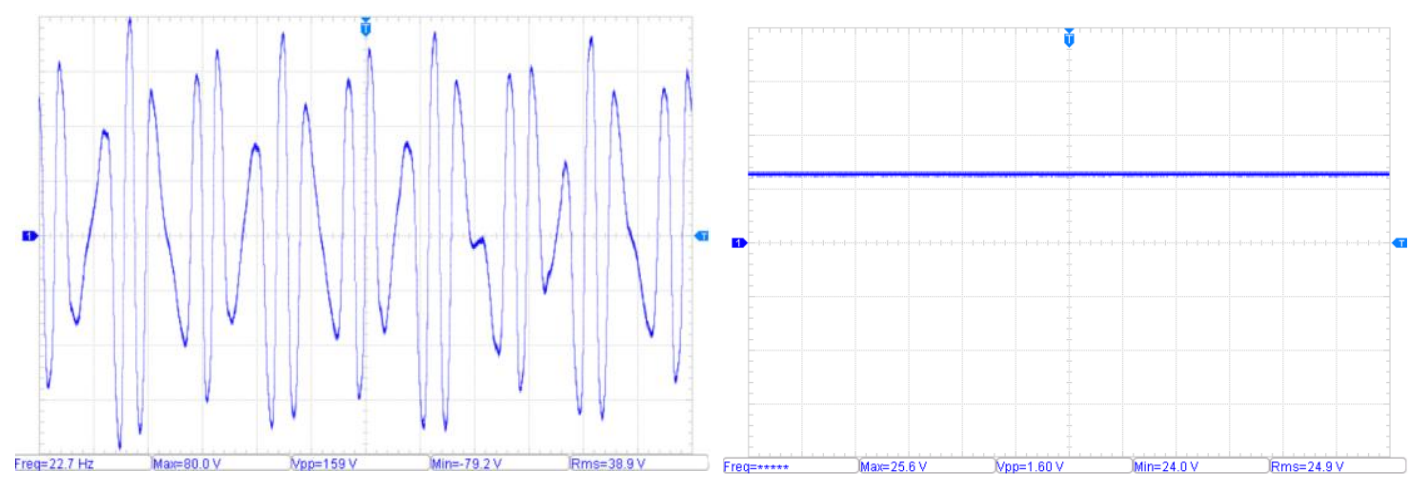

a. Before using Buck-Boost Converter

b. After using Buck-Boost Converter

Figure 7 Signal output voltage of translation motion generators without load using the Buck-Boost Converter

\subsection{Result of Translation Motion Generator Testing with Load 40 W Using 2x1260 Winding Coil}

Translation motion generator testing with load is carried out using $4 \times 10$ watt lamp (16.6 $\Omega$ and $12 \mathrm{Vdc}$ ). The results are shown in Table 3 where it seen that the output voltage generated by the translation motion generator before using the Buck-Boost Converter is $18.1 \mathrm{~V}$ and 0.3 A at rotation speed $100 \mathrm{rpm}$. At rotation speed $200 \mathrm{rpm}$, the output voltage of the translation motion generator with load is $31.7 \mathrm{~V}$ and current $0.48 \mathrm{~A}$. This shows that the rotation speed of generator increase on the translation motion generators produce an increase in voltage and also show that the output generator cannot used for charge of battery during is not stable of voltage.

After using Buck-Boost Converter the output voltage becomes stable at rotation speed 100 to $200 \mathrm{rpm}$ with value voltage 23.93 Volt to 23.95 Volt. This results shows that the output voltage of generator after using Buck-Boost Converter is become stable at 24 Volt. This phenomenon said that by using the Buck-Boost Converter the value of output voltage becomes constant (stable) and can be used for charge of battery.

Table 3 Two-sided testing of generator translation motion (2x1260 winding coil) with load $40 \mathrm{w}$ using a Buck-Boost Converter

\begin{tabular}{cccccc}
\hline $\begin{array}{c}\text { Winding } \\
\text { coil (N) }\end{array}$ & $\begin{array}{c}\text { Rotation } \\
\text { (RPM) }\end{array}$ & \multicolumn{2}{c}{$\begin{array}{c}\text { Before using Buck- } \\
\text { Boost Converter }\end{array}$} & \multicolumn{2}{c}{$\begin{array}{c}\text { After using Buck- } \\
\text { Boost Converter }\end{array}$} \\
\cline { 3 - 6 } & & $\begin{array}{c}\text { Voltage } \\
\text { (V) }\end{array}$ & $\begin{array}{c}\text { Current } \\
(\mathbf{A})\end{array}$ & $\begin{array}{c}\text { Voltage } \\
(\mathbf{V})\end{array}$ & $\begin{array}{c}\text { Current } \\
(\mathbf{A})\end{array}$ \\
\hline \multirow{4}{*}{$2 \times 1260$} & 100 & 18,1 & 0,3 & 23,93 & 0,22 \\
& 120 & 19,1 & 0,32 & 23,93 & 0,25 \\
& 140 & 24,7 & 0,34 & 23,94 & 0,27 \\
& 150 & 27,2 & 0,38 & 23,95 & 0,27 \\
& 170 & 29 & 0,41 & 23,95 & 0,27 \\
& 190 & 31,7 & 0,48 & 23,95 & 0,28 \\
& 200 & 33,6 & 0,5 & 23,95 & 0,28 \\
\hline
\end{tabular}


Anizar Indriani, Ija Darmana, Hernadewita, Ari Setyawan, Hendra

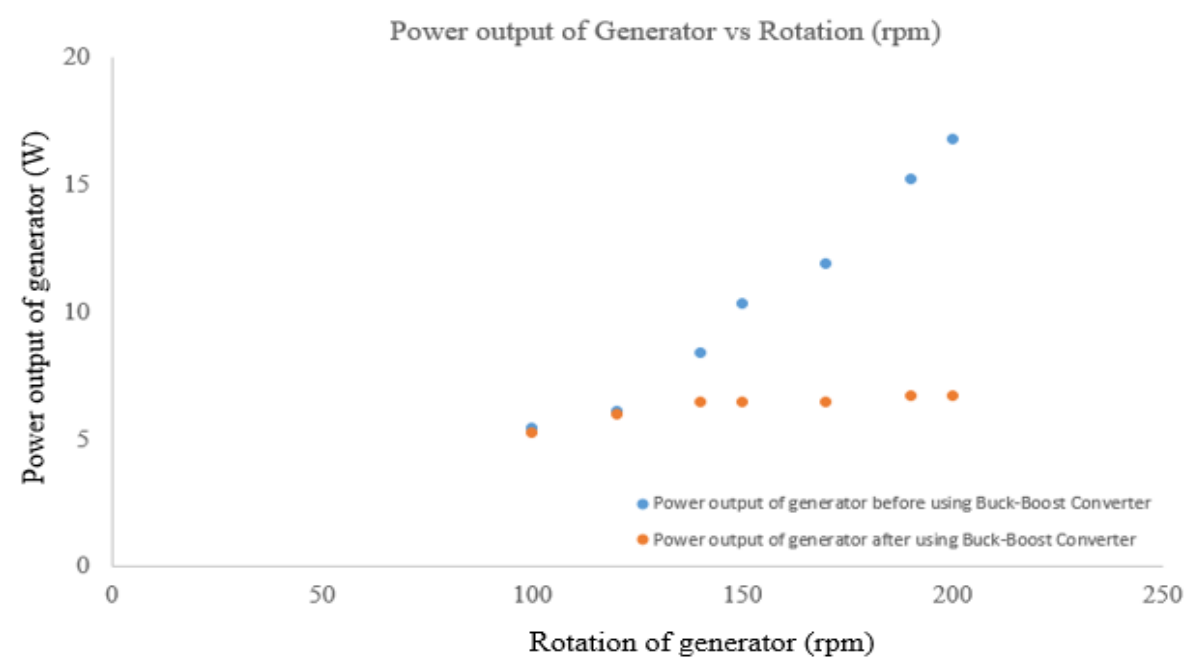

Figure 8 Power of rotation motion generator without load

The power of the translation motion generator by using equation 2 is generated $16.8 \mathrm{w}$ before using the Buck-Boost Converter at rotation speed $200 \mathrm{rpm}$ and after using the BuckBoost Converter is $6.7 \mathrm{w}$. The power generated by variation of rotation speed in the translation motion generator as shown in Figure 8. In Figure 8 show that the power generated by the translation motion generator increases with the addition of rotation speed before using the Buck-Boost Converter. After using the Buck-Boost Converter the power generated by the translation motion generator has a constant value and smaller.

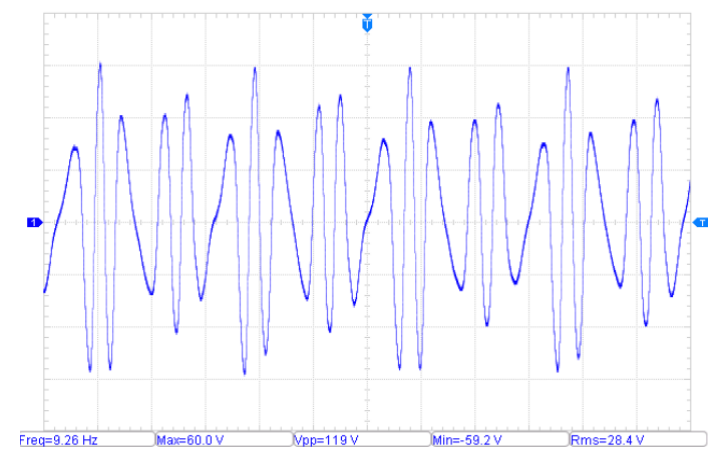

a. Before using Buck-Boost Converter

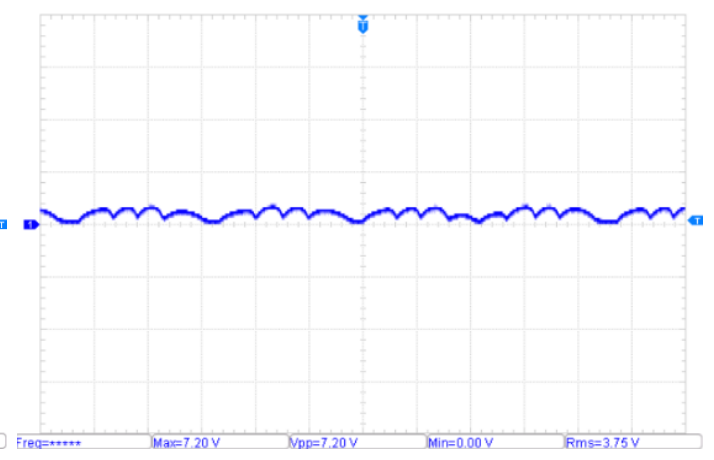

b. After using Buck-Boost Converter

Figure 9 Signal of output voltage of translation motion generators with load $40 \mathrm{w}$ using oscilloscopes at $200 \mathrm{rpm}(2 \times 1260$ coil winding)

The shape of signal power the translation motion generator is measuring by the oscilloscope as shown in Figure 9. Figure 9 a shows that the shape of signal output power before using the Buck-Boost Converter is fluctuation or alternating motion. After using the Buck-Boost Converter the shape of signal output power generated by the translation motion generator tends to be flat as shown in Figure $9 \mathrm{~b}$.

\subsection{Rotation Motion Generator Testing}

Rotation motion generator testing is carried out using a permanent magnet generator (PMG) which produces an output in the form of direct current (DC). 


\subsection{Results of Rotation Motion Generator Testing without Load}

The Testing results of rotation motion generator without load before using the Buck-Boost Converter obtained that the value output voltage of generator is $25.67 \mathrm{~V}$ and $3.78 \mathrm{~mA}$ at rotation speed $100 \mathrm{rpm}$. At rotation speed $200 \mathrm{rpm}$, the value output voltage of generator is $45.5 \mathrm{~V}$ and $6.99 \mathrm{~mA}$. This shows that an increase a rotation speed of generator followed by increasing the value output voltage of generator as shown in Table 4.

After using the Buck-Boost Converter, the resulting output voltage of the rotation motion generator is $22.78 \mathrm{~V}$ at rotation speed $100 \mathrm{rpm}$ and $22.95 \mathrm{~V}$ at rotation speed $200 \mathrm{rpm}$. Similar in the phenomenon translation motion generator test results, the value of the rotation motion generator output voltage tends to be stable and constant. This shows that the use of BuckBoost Converter can keep the output voltage of the rotation motion generator stable, as shown in Figure 10.

Table 4 Testing of rotation motion generator without load

\begin{tabular}{|c|c|c|c|c|}
\hline \multirow[t]{2}{*}{$\begin{array}{c}\text { Rotation } \\
\text { (RPM) }\end{array}$} & \multicolumn{2}{|c|}{$\begin{array}{l}\text { Before using Buck- } \\
\text { Boost Converter }\end{array}$} & \multicolumn{2}{|c|}{$\begin{array}{l}\text { After using Buck- } \\
\text { Boost Converter }\end{array}$} \\
\hline & $\begin{array}{c}\text { Voltage } \\
\text { (V) }\end{array}$ & Isc (mA) & $\begin{array}{c}\text { Voltage } \\
\text { (V) }\end{array}$ & $\operatorname{Isc}(\mathbf{m A})$ \\
\hline 100 & 25,67 & 3,78 & 22,78 & 3,07 \\
\hline 120 & 27,46 & 4,27 & 22,79 & 3,08 \\
\hline 140 & 32,53 & 4,61 & 22,79 & 3,08 \\
\hline 150 & 36,13 & 5,16 & 22,83 & 3,08 \\
\hline 170 & 37,8 & 5,96 & 22,95 & 3,07 \\
\hline 190 & 46,0 & 6,88 & 22,90 & 3,08 \\
\hline 200 & 45,4 & 6,99 & 22,79 & 3,08 \\
\hline
\end{tabular}

The shape of signal output voltage the rotation motion generator using oscilloscope can be seen in Figure 11. Figure 11 a shows that signal of output voltage rotation motion generator before using the Buck-Boost Converter wavy with random shapes. After using Buck-Boost Converter the signal of output voltage of the rotation motion generator becomes constant (stable).

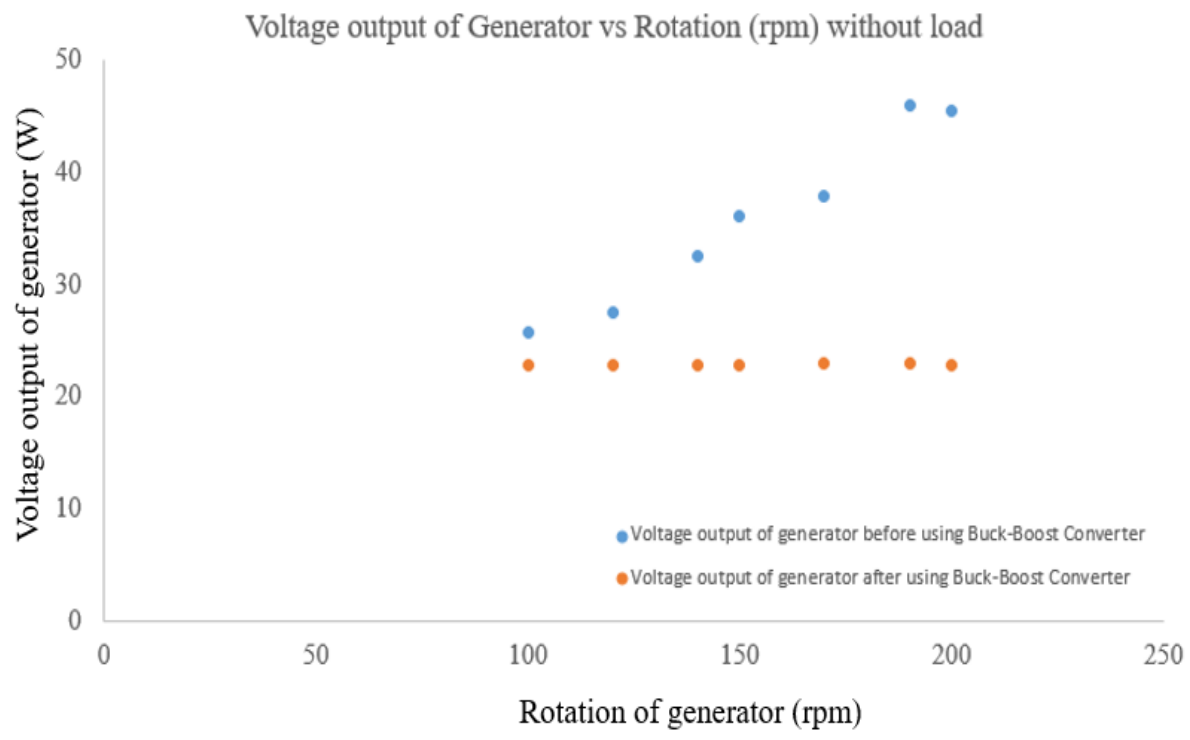

Figure 10 Output voltage of rotation motion generator without load 


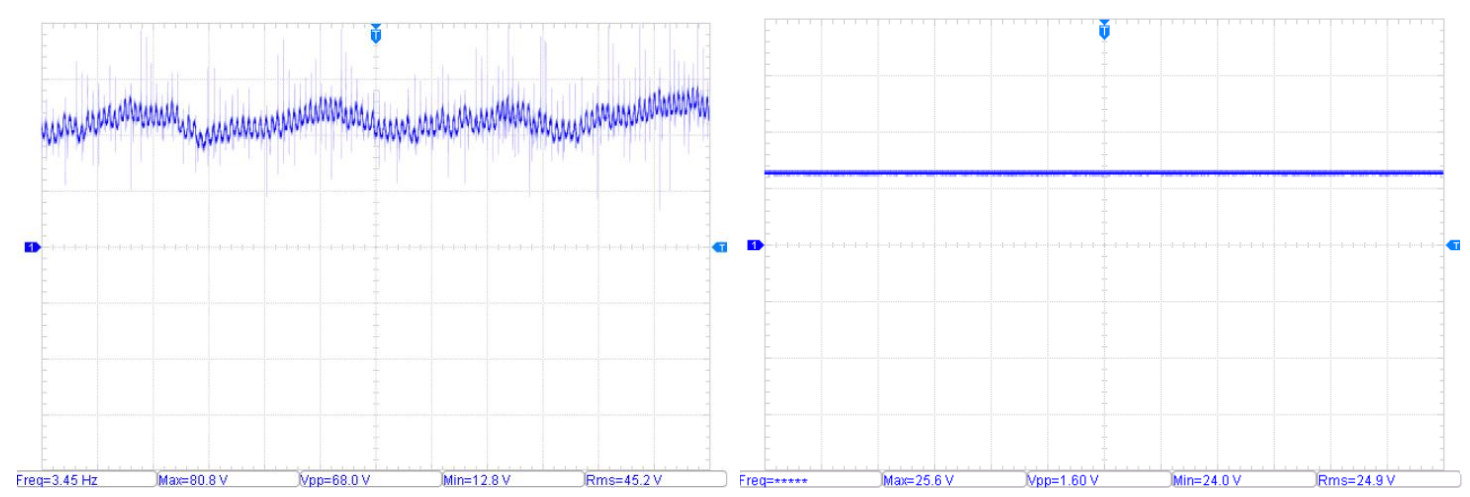

a. Before using Buck-Boost Converter

b. After using Buck-Boost Converter

Figure 11 Signal of output voltage of rotation motion generator without load using oscilloscopes at $200 \mathrm{rpm}$

\subsection{Results of Rotation Motion Generator Testing with Load 12 W}

Results of the rotation motion generator testing with load $12 \mathrm{w}$ and the resistance value 16.6 $\Omega$ before using Buck-Boost Converter is $12.9 \mathrm{~V}$ and $0.38 \mathrm{~A}$ at rotation speed $100 \mathrm{rpm}$. At rotation speed $200 \mathrm{rpm}$, result of the generator output voltage increases to $28.3 \mathrm{~V}$ and 0.52 $\mathrm{mA}$. This result shows that similarly phenomenon with the testing of rotation motion generator without load, where is a biggest value of the generator output voltage happen at highest rotation speed as shown in Figure 12. The output voltage of generator cannot used for charge of battery because fluctuation of voltage can make the battery become fail function or broken.

After using the Buck-Boost Converter, the output voltage of the rotation motion generator produced tends to have a constant value between $24.31 \mathrm{~V}$ to $24.43 \mathrm{~V}$ and 0.29 A to $0.37 \mathrm{~A}$ from rotation speed $100 \mathrm{rpm}$ to $200 \mathrm{rpm}$. This shows that by using Buck-Boost Converter the output voltage of rotation motion generator become stable although happen increasing of rotation speed of generator as shown in Figure 12. This indicates that the generator output can be used to charge the battery.

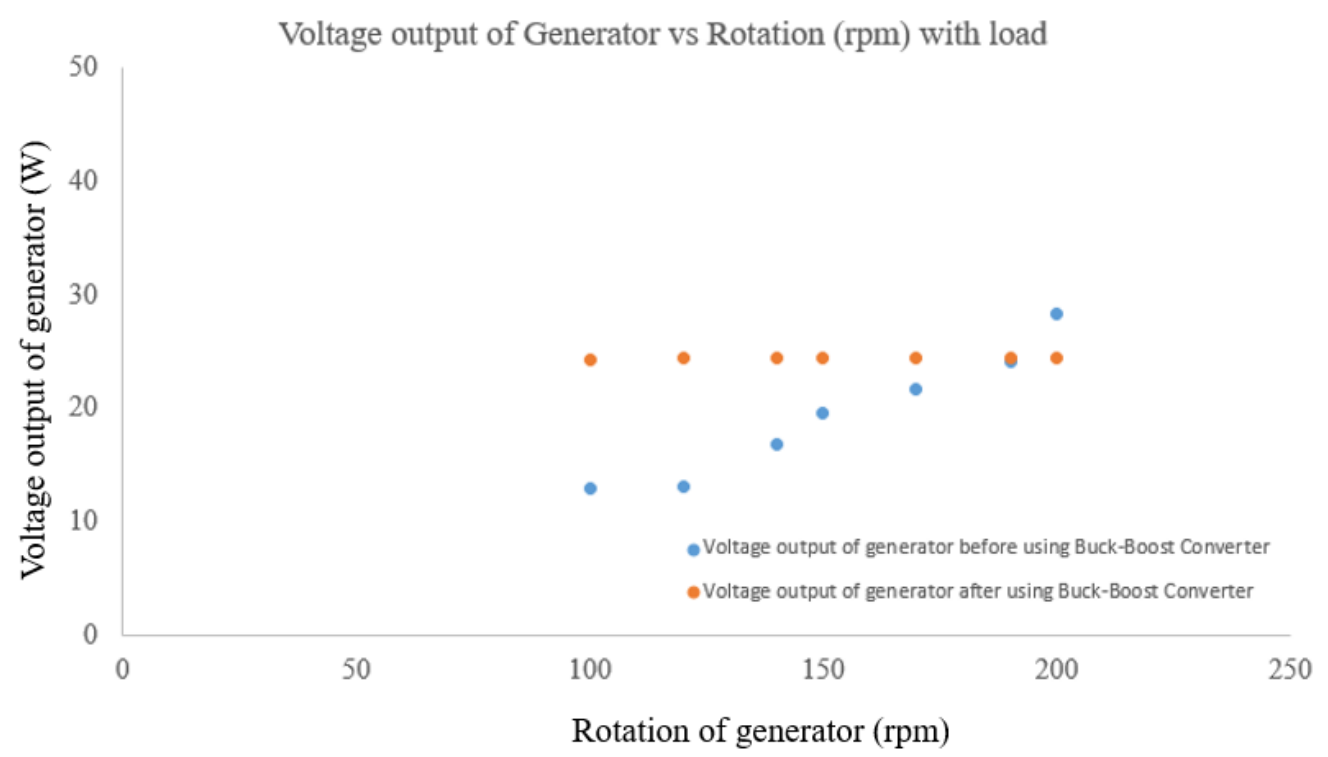

Figure 12 Output voltage of rotation motion generator with load $40 \mathrm{w}$ 
Control Output of Generator Translation and Rotation using Buck-Boost Converter for Sea Wave Power Plant

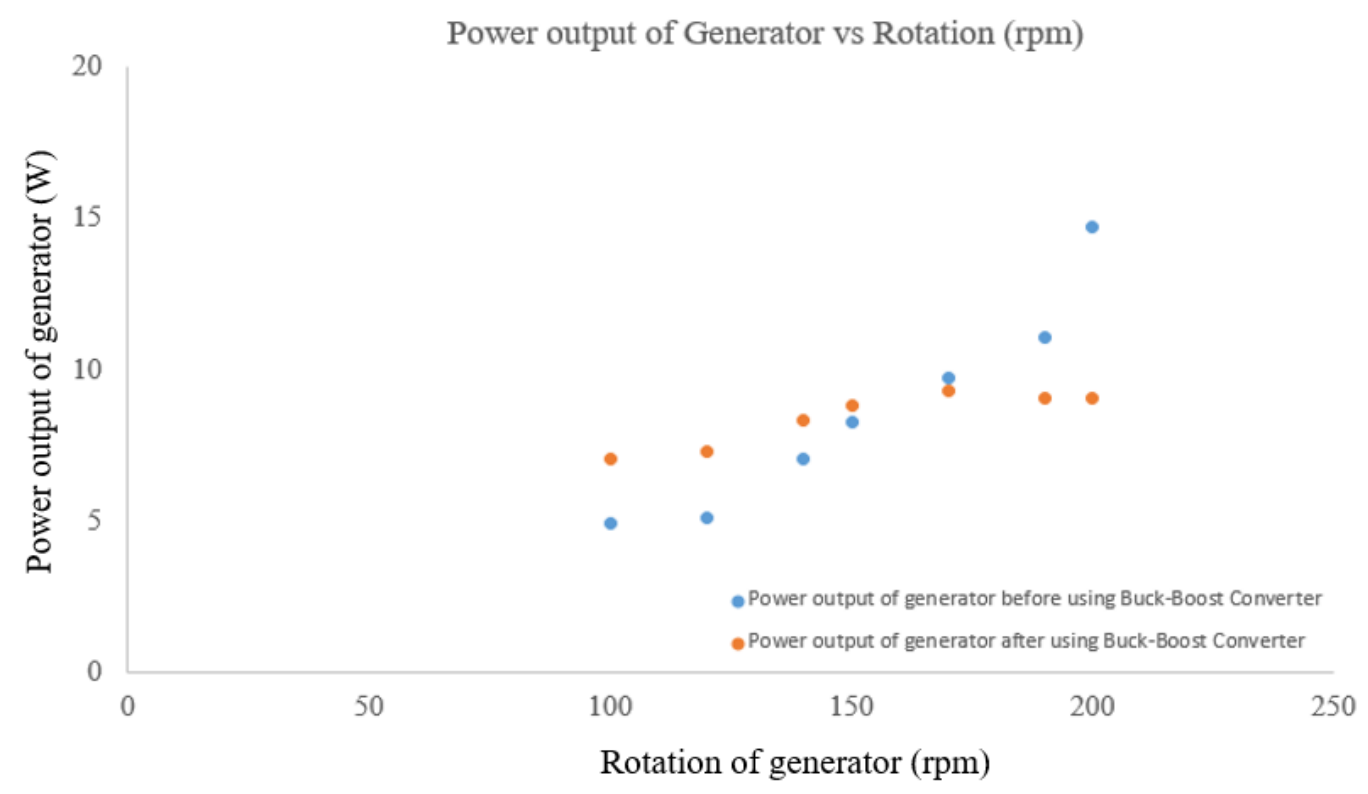

Figure 13 Power output of rotation motion Generator with load $40 \mathrm{w}$

The value power of the rotation motion generator generated by eq. 2 is $14.7 \mathrm{w}$ at $200 \mathrm{rpm}$ for before used the Buck-Boost Converter and $9.03 \mathrm{w}$ after used the Buck-Boost Converter. By rotation variation value of power rotation motion generator can be seen in Figure 13. In Figure 13 it seen that the power of the rotation motion generator increases with the addition of rotation before using the Buck-Boost Converter. After using the Buck-Boost Converter the power of the translation motion generator is smaller and become constant.

The shape of signal output voltage the rotation motion generator with load using oscilloscope as shown Figure 14. Figure 14 a shows that signal of output voltage rotation motion generator with load before using the Buck-Boost Converter wavy with random shapes. After using Buck-Boost Converter the signal of output voltage of the rotation motion generator becomes small and constant (stable).

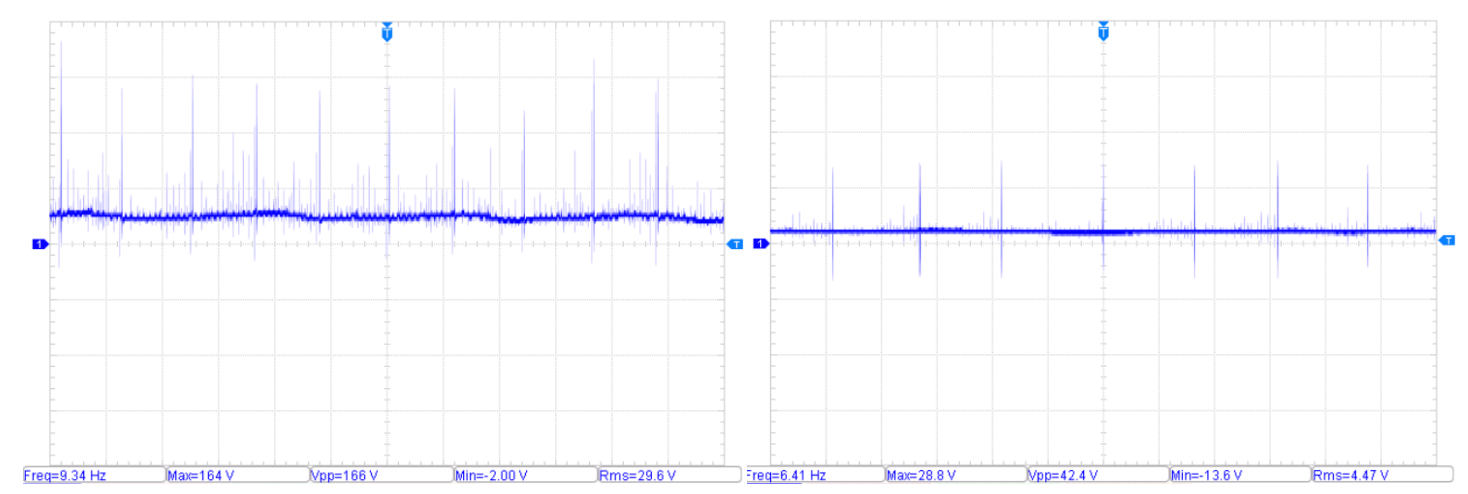

a. Before using Buck-Boost Converter

b. After using Buck-Boost Converter

Figure 14 Signal of output voltage of rotation motion generator with load $40 \mathrm{w}$ using oscilloscopes at $200 \mathrm{rpm}$

\section{CONCLUSIONS}

In this paper, control output voltage of the translation and rotation motion generators using Buck-Boost Converted with load and without load are presented. The conclusion show that : 
- The output voltage of the Buck-Boost Converter has the same value as the input value $(12 \mathrm{~V})$ if the value of duty cycle is equal to $50 \%$. If the duty cycle is below $50 \%$, the output voltage becomes low $(5 \mathrm{~V})$ and otherwise if it passes through the value of $50 \%$ the output voltage value increases $(23.34 \mathrm{~V})$.

- The results of performance of translation and rotation generator (output voltage) depend on the rotation before use Buck-Boost Converter. The value of output voltage generator is increasing by higher value of rotation of generator (18.1-40.14 Volts). In other hand, small value of rotation the value of output voltage become decrease. After use of Buck-Boost Converter, the output voltage of generator become constant despite increased rotation speed.

- By using the Buck-Boost Converter, value of output voltage of generators become stable at $24 \mathrm{~V}$ and also can be used to charge of battery.

\section{ACKNOWLEDGEMENTS}

The authors would like to thank to the Ministry of Research Technology and Higher Education Republic of Indonesia and Institution of Research and Community Service University of Bengkulu for laboratory facilities and financial assistance under Grant Skim Penelitian Dasar Unggulan Perguruan Tinggi No. 791/UN.30.15/LT/2019

\section{REFERENCES}

[1] Hendra, Indriani, A, and Hernadewita, Applying of Piston Mechanism Design used in the Wavelength Electrical Generating of Ocean for Fishing Communities, Advanced Materials Research, 2014, Vol. 918, pp. 73-78, Trans Tech Publications, Switzerland.

[2] Indriani, A, Sitepu, D, Hendra, Effect of Dimension and Shape of Magnet on the Performance AC Generator with Translation Motion, IOP Conf. Series: Materials Science and Engineering, 2018, 307, 012020 doi:10.1088/1757-899X/307/1/012020.

[3] Indriani, A., Hendra, Suhartini, Y., Tanjung, A., Performance of Generator Pneumatic for Power Plant of Ocean Wave, IOP Conference Series: Materials Science and Engineering, 2019, doi:10.1088/1757-899X/505/1/012120.

[4] Falcao, A.F., Wave Energy Utilization: A Review of the Technologies, Renewable and Sustainable Energy Reviews, 2010, Vol. 14, pp. 899-918.

[5] Rodrigues, L, Wave Power Conversion Systems for Electrical Energy Production, Dept. of Electrical Engineering, Faculty of Sciences and Technology, Nova University Lisbon, Portugal, 2007.

[6] Anand, S, Turbines for Wave Energy Plants, Proceedings of the $8^{\text {th }}$ International Symposium on Experimental and Computational Aerothermodynamics of Internal Flows, 2007, Lyon.

[7] Amundarain, M, Alberdi, M, Garrido, J, and Garido, I., Modeling and Simulation of Wave Energy Generation Plants: Output Power Control, IEEE Transactions on Industrial Electronics, 2011, Vol. 58, and No.1.

[8] Casman, D.P., Sullivan, D.L., Egan, M.M., and Hayes, J.G., Modeling and Analysis of an Offshore Oscillating Water Column Wave Energy Converter, Proceedings of the $8^{\text {th }}$ European Wave and Tidal Energy Conference, 2009, pp. 924-933, Sweden.

[9] Neelaman, S., Wave Interaction With Floating Wave Energy Caisson Breakwaters, Journal of Coastal Research, 2006, Special Issue 39. 
Control Output of Generator Translation and Rotation using Buck-Boost Converter for Sea Wave Power Plant

[10] Rane, S., Chaudhary, M., Barai, S., Prajapati, L., Choudhari, M., Permanent Magnetic Generator, International Journal of Science and Engineering, Vol. 1, Issue 10, 2015.

[11] Theja, V. S. V, Sriramalakshmi, P., Comparison of Conventional Buck and Boost Converter with Integrated Dual Output Converter, International Journal of Pure and Applied Mathematics, Vo. 117, No. 16, 2017.

[12] Nugrahani, F., Riawan, C. D., Ashari, M., Perbaikan Kualitas Arus Output pada BuckBoost Inverter yang Terhubung Grid dengan Menggunakan Metode Feed-Forward Compensation (FFC), Jurnal Teknik POMITS, Vol 1, No.1, 2012. 